\title{
Lean Commercialization: A New Framework for Commercializing High Technologies
}

\author{
Saheed A. Gbadegeshin
}

\author{
(6 After filing a patent, your job is only quarter done." \\ And, to achieve patent commercialization success, \\ every inventor must think like a business man. \\ Kalyan C. Kankanala \\ Author and Intellectual Property Attorney
}

\begin{abstract}
Commercializing high technologies is expensive, tedious, and resource intensive. Meanwhile, there is a need for quick diffusion of innovations due to economic pressures for companies and research institutes. Therefore, this article proposes a new framework: lean commercialization. The framework represents a transformation of new technology and knowledge to products and services through the application of the lean/agile methodology. This methodology focuses on how resources can be minimized during the development, manufacturing, and marketing of new products and services, while still being accepted by customers. The lean commercialization framework was developed from a case study of high-technology companies and by interviewing commercialization experts. This article contributes to the theory and practice of commercialization of high technologies and provides a procedure for the practical application of the lean commercialization framework.
\end{abstract}

\section{Introduction}

Commercialization is series of activities that transform an innovation to a final product or service from which economic benefit can be derived (Meyers, 2009; Perkmann et al., 2013; Rosa \& Rose, 2007; Speser, 2008). Presently, there is pressure on research institutes and their scientists to commercialize innovations due to limited funding for basic research. Therefore, searching for new means of commercialization is essential (Gbadegeshin, 2017a; Still, 2017). Here, we examine on such means, which is the application of the lean/agile methodology to commercialization activities (Apilo et al., 2015; Gbadegeshin, 2017a; Kruuti, 2016). Lean is an effort to eliminate waste while developing high-quality products and services. This principle relies on improvements in production, administration, and strategies of organization (Kilpatrick, 2003).

One of well-known lean/agile approaches is the lean startup methodology. It was propounded by Ries (2011) and it has been applied by scholars in various contexts, such as healthcare (e.g., Gaffney et al., 2014; Silva et al., 2013), biotechnology (e.g., Shimasaki, 2018; Kruuti, 2016; Grohn et al., 2015), education (e.g., Tran, 2015; Youtie \& Shapira, 2017), research (e.g., Still, 2017), technology-based ventures (e.g., Harms et al., 2015), and information and communication technology (e.g., Gbadegeshin \& Heinonen, 2016; Ibba et al., 2018; Miski, 2014).

In applying the lean startup methodology to commercialization, a new term is proposed: "lean commercialization". Lean commercialization applies the lean startup methodology to the commercialization process, with the primary goals of eliminating waste and minimizing resource expenditures on technology development, manufacturing, and marketing of new products and services. This new approach also aims to create sustainable businesses around new technologies.

The lean commercialization framework proposed in this article is based on empirical studies on commercialization activities of technology-based companies, their technologies after commercialization, and the experience of business advisors. A case study approach was employed by interviewing the founders of the companies and observing their high technologies, and by interviewing business advistors. Two serial entrepreneurs were interviewed in 2012, their commercialized technologies were monitored from 2012 to 2016, and four commercialization experts were interviewed in 2017. 


\section{Lean Commercialization: A New Framework for Commercializing High Technologies Saheed A. Gbadegeshin}

This study makes a theoretical contribution by proposing a new commercialization logic. It also makes a theoretical contribution by providing a framework which can be used by the technology entrepreneurs and technology-based enterprises. The study makes a practical contribution through its framework, which assists technologists and scientists in their commercialization adventures.

\section{Theoretical Background}

\section{The lean startup methodology}

Entrepreneurs, scholars and companies are interested in lean startup methodology because of its role in innovation and the development of new products and services (Blank, 2013; Blank et al., 2013; Gaffney et al., 2014; Moogk, 2012). Hence, since 2008, it has been the subject of many scholarly articles, books, and blog posts (Gaffney et al., 2014). The method was initially developed for the entrepreneurs and startups, but due to its broader applicability and potential benefits, larger and more mature companies are now also employing it (Apilo et al., 2015; Blank, 2013; Gaffney et al., 2014; Hakin, 2014). Likewise, tertiary institutions are inculcating it into their curricula (Wright et al., 2017; Youtie \& Shapira, 2017).

The primary underpinnings of the lean startup methodology are to ensure efficiency and effectiveness, minimize wastes, and produce acceptable products and services. The method employs a build-measure-learn feedback loop that enables an individual person or company to build and verify an idea or innovation. It also enables them to learn from test results. The lean startup methodology encourages validated learning and experimentation (Blank, 2013; Ries, 2011). Similarly, the method assists enterprises to arrive at viable business models using minimal resources (Furr et al., 2014; Gaffney et al., 2014).

The lean startup methodology has five key principles that are both simple and straightforward: entrepreneurs are everywhere, entrepreneurship is management, validated learning, innovation accounting, and build-measure-learn (Ries, 2011). The first principle, "entrepreneurs are everywhere", denotes that those who see and utilize an opportunity can be found at any place, including large enterprises. The second principle, "entrepreneurship is management", means that the process of utilizing opportunities need to be well planned and executed, which will lead to lessons learned. In turn, these lessons account for the third principle, which is "validated learning". The fourth and fifth principles, "innovation accounting" and "build-measure-learn" are more practical, and they constitute the application aspect of the lean startup methodology (Gaffney et al., 2014). Put another way, the salient features of the lean startup methodology are the development of a minimum viable product, market testing of the minimum viable product, collecting and analyzing market test data, and learning from the test results (Donelan, 2013).

Therefore, the application of lean startup methodology is an iterative execution of the build-measure-learn loop. It is a development of a prototype (in the case of a physical product) or a service sample (in the case of a non-physical product) followed by testing and redesign based on the test results. The iteration makes the entrepreneurs and companies understand needs, wants, and preferences of their customers (Hart, 2012; Järvinen et al., 2014; Ries, 2011).

Applying a lean methodology ensures better and faster development of successful products and services (Apilo et al., 2015; Hemilä \& Jaring, 2018; Maurya, 2012). The benefits of the method include:

- reduction of the lifecycle of new product development

- minimization of resource wastes (Furr et al., 2014; Moogk, 2012; Ries, 2011)

- more efficient and effective new product or service development (Blank, 2013; Gaffney et al., 2014; Ries, 2011)

- facilitation of customer acceptable products or services (Gaffney et al., 2014; Järvinen et al., 2014)

- usefulness in extreme uncertainty conditions (Blank, 2013; Järvinen et al., 2014; Ries, 2011)

- facilitation of commercialization processes of startups, small companies, and multinational companies (Gbadegeshin \& Heinonen, 2016; Harms et al., 2015; Kruuti, 2016; Moogk, 2012).

Notably, the lean startup methodology is different from a traditional business development approach. Blank (2013) and Järvinen and colleagues (2014) elucidate that the lean startup methodology can be distinguished from the traditional approaches in relation to strategy, new product development, organization structure, and 


\section{Lean Commercialization: A New Framework for Commercializing High Technologies Saheed A. Gbadegeshin}

operational perspectives. First, the strategy of the lean startup methodology results in the development of a suitable business model, whereas the traditional approach is an execution of a business plan. Second, the lean startup methodology focuses on the development of customers and a market, whereas the traditional method concentrates on product development. Third, the organizational structure of the lean startup methodology consists of customer and agile development teams, which are not present in the traditional method. Last, the lean startup methodology makes use of metrics, accepts failure, and appreciates customer feedback; these features are lacking in the traditional approach.

\section{Case studies: Applying the lean startup methodology in} commercialization

Common features of high technologies are novelty, complexity, resource intensity, and high levels of R\&D (Schrier \& Hallin, 2017; Steenhuis \& de Bruijn, 2006). These features make high technologies full of risks and create uncertainty for their commercialization (Furr et al., 2014). However, several case studies have shown that these high-technologies could be commercialized with the lean startup methodology. For example, Shimasaki (2018) affirms that the methodology enabled a biotechnology company to commercialize its product through validated learning and iterations. The author concludes that:

"For those contemplating starting a biotechnology company, or those in a development stage company, making use of capital efficiency and lean startup, openinnovation frameworks can leverage the capital raised, and greatly improve your likelihood of success."

In a similar example, Kruuti (2016) found in his case study that the application of the lean startup methodology assisted a multinational company in understanding its unfamiliar market and in establishing relationships with its new consumers. He argued that this methodology made the company and its commercialization team develop their new technology in accordance with the needs and wants of the consumers. Looking into another high-tech industry, Harms and colleagues (2015) emphasized that the lean startup methodology reduces market uncertainty for the material sciences industry. These scholars stated that the methodology promotes a technology commercialization process in relation to their case studies. In a digitalization context, Ibba and colleagues (2018) confirmed that the lean startup methodology played an important role in solving crucial challenges facing the commercial- ization of digitalized technologies and products. These scholars found that their case study companies employed pivoting, validated learning, testing, and feedback to overcome their commercialization bottlenecks. All these scholars stated that, to accelerate and scale commercialization activities, the application of the lean startup methodology would be beneficial.

\section{Current frameworks for the application of the lean star- tup methodology}

Considering the lean startup methodology, its logic, and its benefits, many frameworks have been developed by scholars. Most of the frameworks are based on the work of theorists, such as Ries (2011) and his associates such as Blank (2013) and Furr and colleagues (2014). Likewise, many frameworks have been developed in further applications of the main theory (e.g., Gbadegeshin \& Heinonen, 2016; Järvinen et al., 2014; Lalic et al., 2012; Munch et al., 2013).

Due to the nature of high-technologies and their industries, the need for rapid commercialization, the need for skillful personnel to manage business operations, the importance of customer satisfaction, and the emergence of the digitalization phenomenon (Hemilä \& Vanhanen, 2016), the lean startup methodology is linked to the term "acceleration" (Hemilä \& Jaring, 2018). Acceleration refers to methods, tools, and processes that entrepreneurs and companies employ to make their new offers available in the market (Apilo et al., 2015). The acceleration framework is quite similar to the lean startup methodology, and it was developed from the lean startup methodology and other agile methods, such as effectuation, creation theory, business modelling, and experimentation. The framework consists of four stages: idea, high-value concept, validated minimum viable solution, and scale solution (Apilo et al., 2015). These stages mean that a need or problem has to be discovered; then, possible solutions need to be identified and tested. When these activities are achieved, there should be a focus on the scalability of the solution in order to make business sustainable (Hemilä \& Jaring, 2018).

Furthermore, Furr and colleagues (2014) extend the lean startup methodology by inculcating the business model to the framework, which they describe as the "innovator's method". Their framework consists of four stages: insight, problem definition, solution prototyping, and business model creation. Moreover, they extended the concept of the minimum viable product, even going so far as to label it the "minimum awesome 


\section{Lean Commercialization: A New Framework for Commercializing High Technologies Saheed A. Gbadegeshin}

product" (Erickson, 2015). All of the above frameworks contain prototyping or a minimum viable product, testing or experimentation, results analysis, and validated lessons. Thus, these are key activities of the lean startup methodology.

\section{A recent framework for the application of lean startup to} the commercialization of innovations

The author and a co-author (Gbadegeshin \& Henionen, 2016) recently proposed a framework for the application of the lean startup methodology to the commercialization process, as depicted in Figure 1. We developed this framework from a study on the commercialization of business ideas and innovations. The framework describes six stages in the application of the lean startup methodology in commercialization. The stages are: Googling the idea or new technology, developing uniqueness, conceptualizing the new technology, developing prototypes, testing prototypes, and analyzing test data. Following testing, if the results are positive, the commercialization team can make a "preserve" decision by engaging in mass production and marketing of the new technology. If the test result is neutral, the commercialization team can "pivot". However, if the result is negative, the commercialization team could restart their commercialization process.

Before applying the framework, the commercialization team needs to consider the following factors:

- The team must have adequate knowledge about the lean startup methodology.

- There must be a clear expectation that challenges will occur in the early stages of applying the lean startup methodology for the first time. Examples of these challenges are an inability to develop a minimum viable product in a short timeframe, disappointments from subcontractors, and an unwillingness of potential customer to try prototypes.

- Potential customers (i.e., the testers) must be made aware that a minimum viable product is not a final product.

- There must be a plan for expansion in case the test is successful, and it must consider the nature and type of offer (product or service), the commercialization phase, and the required team.

\section{Methodology}

This study employed a qualitative research method using a case study approach. This method is useful when an issue is being studied in its natural environment. It allows researchers to understand the issue deeply by making use of real-life conditions. Thus, the method also assists the researchers in interpreting their findings as well replicating their study (Denzin \& Lincoln, 2000). The method is highly relevant for empirical studies and for theory building (Creswell, 2009; Eriksson \& Kovalainen, 2008). One of the strengths of this method is making use of many pieces of evidence such as documents, observations, interviews, and artifacts (Yin, 2003). However, a systematic procedure must be used when applying the method (Creswell, 2009) so that trustworthiness can be demonstrated, which is crucial for the validity and reliability of a study (Eriksson \& Kovalainen, 2008; Morse et al., 2002). The following subsections detail the exact methodological process used in this study.

\section{Study participants}

The empirical part of this study has three phases: initial interviews (2012), observation of technology commercialization (2013-2016), and retrospective interviews

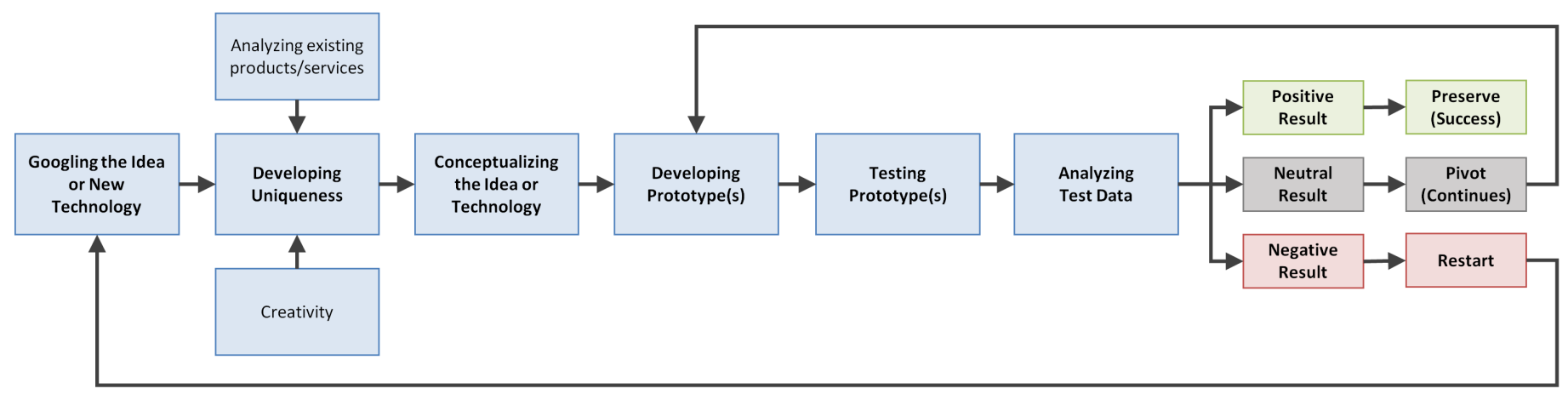

Figure 1. Application of the lean startup to the commercialization of technologies (Adapted from Gbadegeshin \& Heinonen, 2016) 


\section{Lean Commercialization: A New Framework for Commercializing High Technologies Saheed A. Gbadegeshin}

(2017). The study participants in the first phase were selected based on their experience as successful serial technology entrepreneurs in Finland. The participants were expected to be a serial entrepreneur with more than 20 years' experience in commercialization of high-technologies. Although many Finnish technology entrepreneurs were contacted, very few showed interest and two ultimately agreed to participate. However, the two participants offered the opportunity for an in-depth analysis of their commercialization experiences and technologies. The primary aim of this phase was to understand their logic in commercializing high-technologies. After their interviews, these participants gave permission to observe their technologies (products, services, and solutions). This observation period corresponds to the second phase of this study.

Only the high-technologies developed by the participants were considered, and they were selected based on these criteria: the technology must be developed from a basic research or have high-level of R\&D activities; it must have process and product complexities; it must employ state-of-the-art or cutting-edge knowhow; and it must be associated with advanced economic growth and technological development. These criteria align with recommendations by Wong (1990), Steenhuis and de Bruijn (2006), and Schrier and Hallin (2017). The observed technologies came from various sectors - electronics, cleantech, healthcare, chemical production, and information technology - which were categorized as high-tech industries according to Eurostat (2016).
In the third phase of the study, participants were selected based on their expertise as a government official business advisors with more than 20 years' experience. Among the many business advisors contacted in Finland, four were able to participate in face-to-face interviews for this study. Table 1 describes the study participants interviewed in the first and third phases of the study.

\section{Data collection and analysis}

The data were collected through interviews during the first and third phases. These interviews were conducted face-to-face, recorded, and later transcribed. Data collection during the second phase focused on observing the commercialization activities of the companies, but it was supplemented with information from public and government databases.

The collected data were analyzed with a content analysis tool that enabled the reduction of bulk qualitative data through codification, theme development, and result reporting (Creswell, 2009; Miles \& Huberman, 1994). Next, the collected data were first read by the author of this article several times, who made notes. The notes from each phase were later combined to develop different codes. Thereafter, codes were collated by naming each phase. The first phase was named "commercialization activities", the second phase was named "technology progress", and the last phase was named "expert validation". Then, the codes from each phase were summarized and themes were assigned to the codes. Finally, the themes were summarized to produce the final results of the study.

Table 1. Overview of the participants interviewed in this study

\begin{tabular}{lcl}
\hline Phase & Interviewee & Background \\
\hline Phase 1 (2012) & 1 & PhD, founded 5 companies, and presently works as a Chief Engineer in one of the companies. \\
2 & PhD, co-founded 6 companies, and presently works as CEO of two co-founded companies.
\end{tabular}

Phase 3 (2017)

3

4

5

6
MSc, previously worked as an R\&D Manager, and presently works as a Senior Business Advisor for new high-tech companies.

$4 \quad \mathrm{PhD}$, founded 3 companies, and presently works as a Senior Business Advisor for new hightech companies.

PhD, previously worked as an R\&D manager and a Business Development Manager, and presently works as a Senior Business Advisor for new high-tech companies.

$\mathrm{PhD}$, previously worked as an Innovation Manager and an Entrepreneurship Manager, and presently works as a CEO/Business Advisor of a venture capital company for new high-tech companies. 


\section{Lean Commercialization: A New Framework for Commercializing High Technologies Saheed A. Gbadegeshin}

The entire research methodology is summarized in Figure 2, which also reflects the structure of this article.

\section{Results and Discussion}

\section{Application of the lean startup methodology to the com- mercialization process}

The first empirical phase revealed that the serial technology entrepreneurs employed lean startup logic, though these entrepreneurs did not know about the lean startup methodology. These serial technology entrepreneurs applied the logic by focusing on better utilization of their available resources, minimization of waste, and maximization of business opportunities associated with their new technologies. These entrepreneurs believed that little or small resources needed to be invested in initial commercialization activities, while hoping for the best. They made it known that more in- vestment could be added when the new technology started to generate some income. This result aligns with the claims of several authors about the benefits of the lean startup methodology (Gaffney et al., 2014; Gbadegeshin \& Heinonen, 2016; Ibba et al., 2018; Järvinen et al., 2014; Kruuti, 2016; Moogk, 2012; Shimasaki, 2018).

Furthermore, these serial technology entrepreneurs believed in the simultaneous development of customer and market. To do so, they preferred to have direct contact with end users of their new technologies and to acquire as much market information as possible. They also ensured that they piloted their technologies before full commercialization. This belief and their effort correspond to descriptions of several authors with regards to the application of the lean startup methodology (e.g., Blank, 2013; Blank et al., 2013; Furr et al., 2014; Harms et al., 2015; Kruuti, 2016).

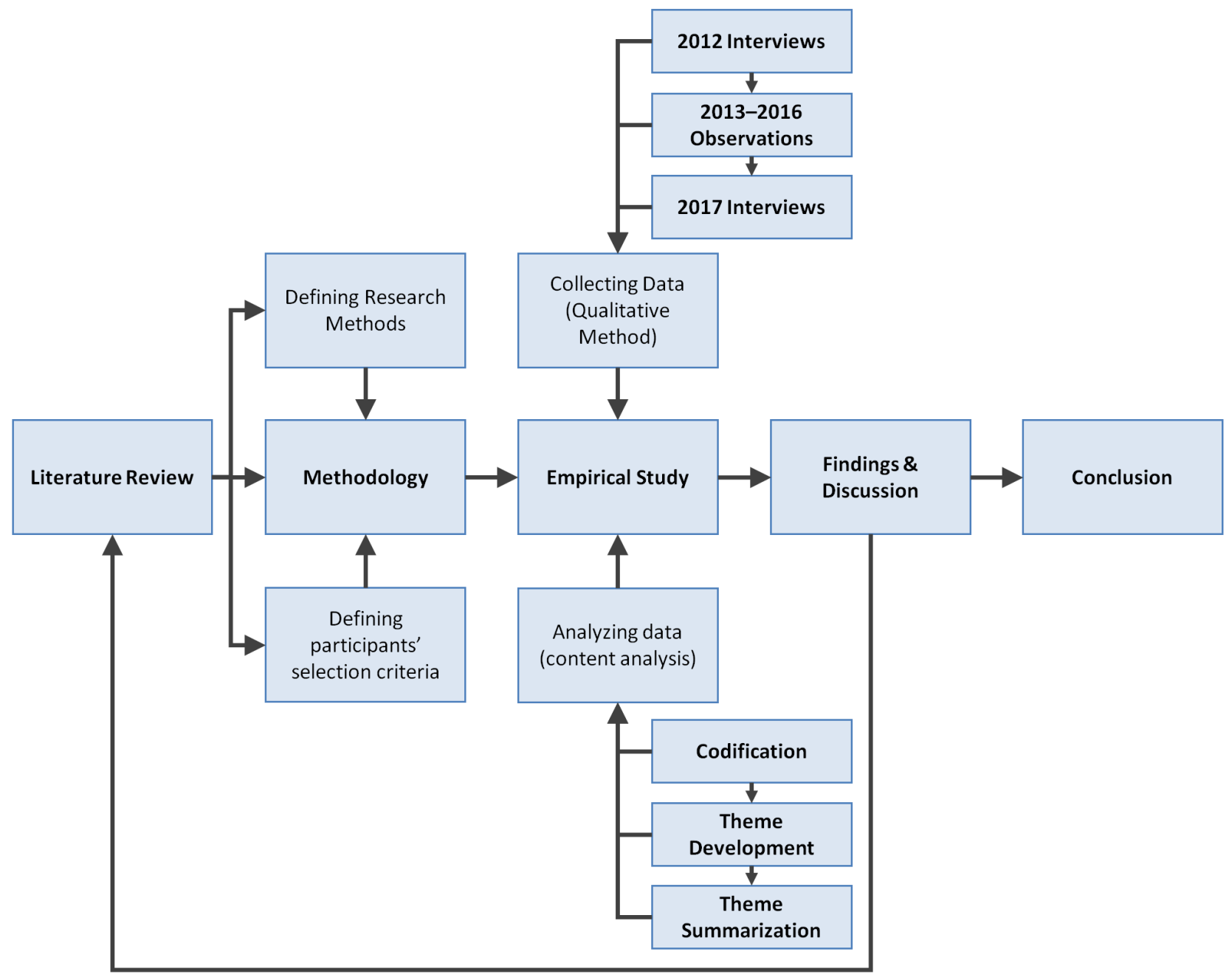

Figure 2. Overview of the methodology followed in this study 


\section{Lean Commercialization: A New Framework for Commercializing High Technologies Saheed A. Gbadegeshin}

Moreover, it was noted that their commercialization process consisted of four stages - pre-commercialization, actual commercialization, new-pre commercialization, and post-commercialization - as found previously by this author Gbadegeshin $(2017,2018 a)$. Figure 3 shows the author's interpretation of the commercialization process described by the study participants, including the different activities undertaken in each phase.

Figure 3 has similarities with the initial lean startup methodology framework, based on the work of Ries (2011) and others (e.g., Apilo et al., 2015; Blank, 2013; Furr et al., 2014; Hemilä \& Jaring, 2018). The commercialization stages of Figure 3, and their various activities, appeared similar in all observed high-technologies in this study, despite being sold in different industrial sectors. The commercialization process also seemed to follow lean the startup methodology pattern as explained in the literature (Blank, 2013; Gaffney et al., 2014; Järvinen et al., 2014; Lalic et al., 2012; Munch et al., 2013; Ries, 2011).
Similarly, the four business advisors interviewed in phase 3 confirmed that firms are following the process described above while explaining that commercialization activities have changed over the last two decades. These experts observed that, two decades ago, technology entrepreneurs focused on functionality, efficiency, and high quality, instead of problem solving and customer acceptance. Their affirmation corresponds to the focus of recent frameworks of the lean startup methodology (Apilo et al., 2015; Furr et al., 2014; Gbadegeshin \& Heinonen, 2016; Hemilä \& Jaring, 2018). The experts also made it known that startup phenomenon, digitalization influences, and "money making" pressures are compelling entrepreneurs to apply lean startup logic as some authors have also noted (e.g., Apilo et al., 2015; Ibba et al., 2018; Kruuti, 2016; Shimasaki, 2018). Thus, the experts emphasized that, in the last five years, lean startup logic has been spreading among technology entrepreneurs, though they also acknowledged that it can be difficult to use. This result confirmed the claim of Gbadegeshin and

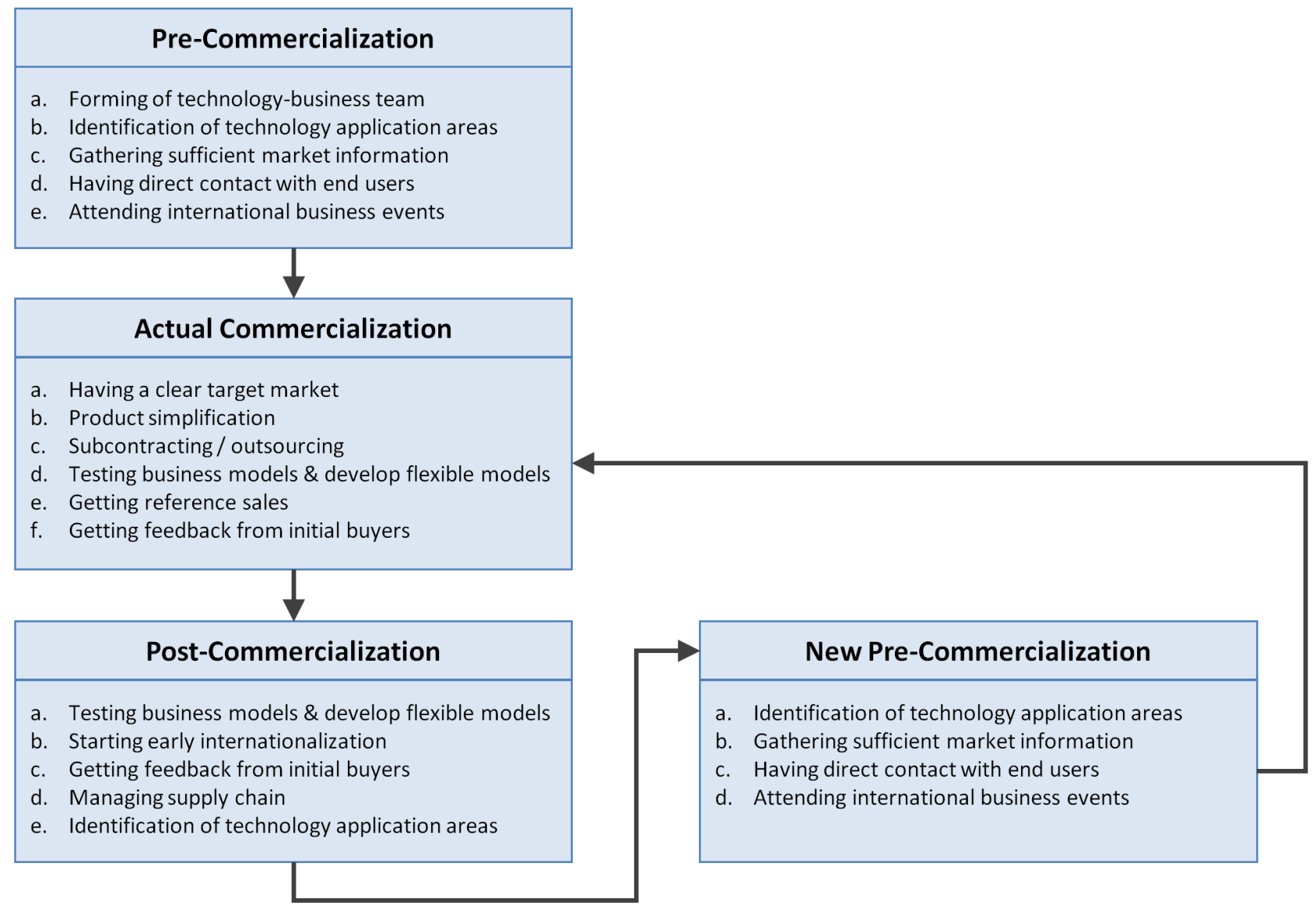

Figure 3. The commercialization process of high technologies 


\section{Lean Commercialization: A New Framework for Commercializing High Technologies Saheed A. Gbadegeshin}

Heinonen (2016) that the application of lean startup methodology might be problematic for the entrepreneurs due to its initial challenges, such as the development of a minimum viable product in a short timeframe and the need to convince potential customers to try prototypes.

In addition, the experts enumerated that insufficient knowledge about the lean startup methodology, belief that the lean startup methodology is for "ICT people", and following of personal preference or intuition are reasons many technology entrepreneurs choose not to apply the lean startup methodology, as some scholars have also noted (e.g., Apilo et al., 2015; Hemilä \& Jaring, 2018; Shimasaki, 2018). Meanwhile, the experts noted that young entrepreneurs seemed to use the lean startup methodology more than older entrepreneurs; likewise, experienced or serial entrepreneurs also use the lean startup methodology. This preference among younger entrepreneurs was noted by Wright and colleagues (2017) when explaining ecosystems of student entrepreneurship. Additionally, the experts regarded the lean startup methodology as a tool, which can be replaced or changed.
In summary, the interviews with the study participants confirmed that the lean startup methodology could be applied in commercializing high-technologies, even without the active awareness of the logic among those undertaking the commercialization activities. However, the participants also agreed that limited knowledge of the lean startup methodology could be an obstacle to the successful application of the logic. In view of these findings, there is indeed a need for a framework to enlighten and guide technology entrepreneurs in applying lean startup methodology in their commercialization adventures.

Development of the lean commercialization framework In responding to this need for knowledge and guidance, a new framework titled "lean commercialization" was developed, as shown in Figure 4. The framework is an application of the lean startup logic to the commercialization process, and it serves as a guide for high-tech entrepreneurs.

Lean commercialization starts with "Evaluating new technology", which is common to most commercialization processes (for examples, see: Abd Rahim et al.,

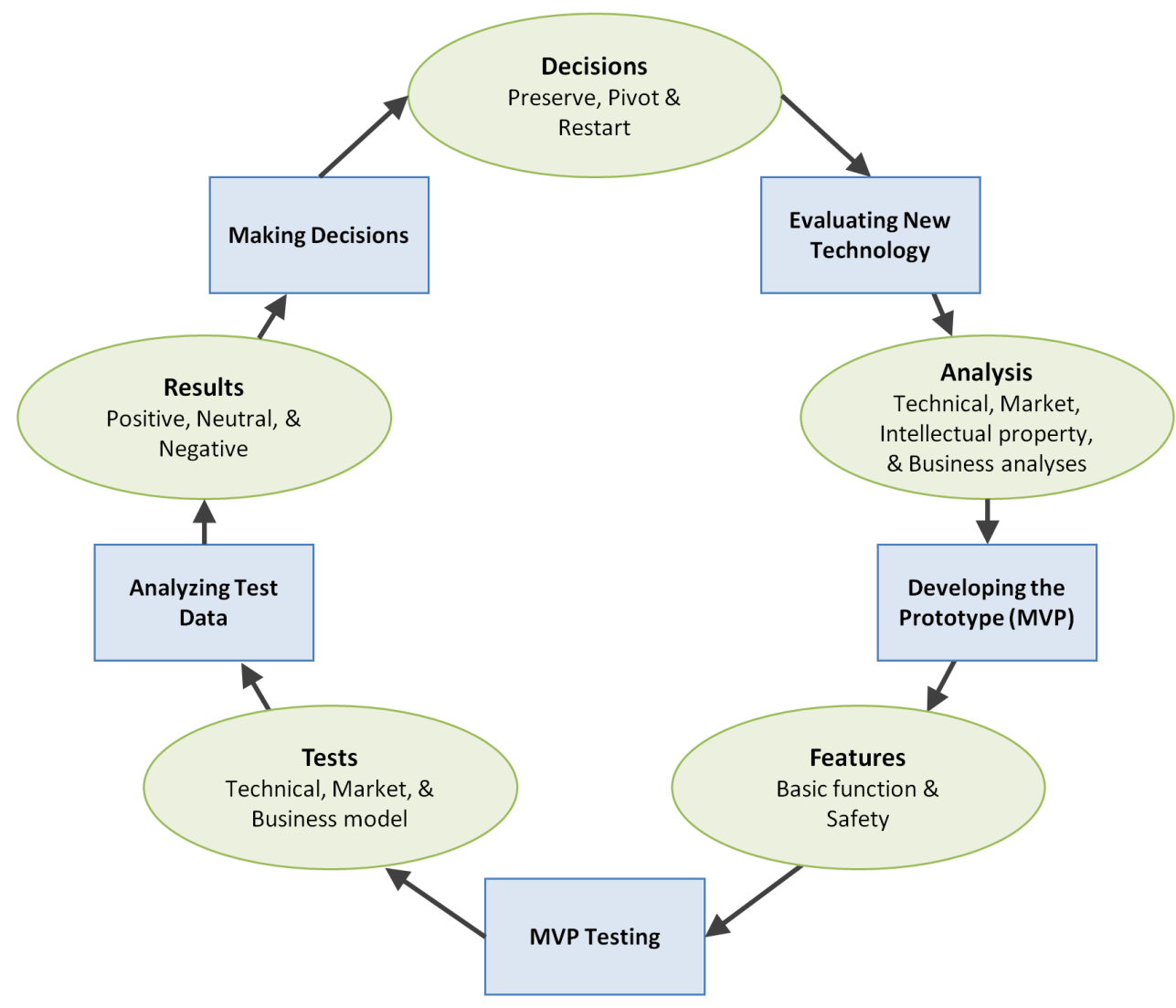

Figure 4. The lean commercialization framework 


\section{Lean Commercialization: A New Framework for Commercializing High Technologies Saheed A. Gbadegeshin}

2015; Al Natsheh et al., 2014; Amadi-Echendu \& John, 2008; Amadi-Echendu \& Rasetlola, 2011; Bradley et al., 2013; Eldred \& McGrath, 1997; Maine \& Garnsey, 2007). This activity is expected to consist of an analysis of technical and market issues and intellectual property. These analyses are essential for commercialization and building a technology-based company (Al Natsheh et al., 2013). However, this activity is not limited to these analyses. Other analyses related to human resources, material acquisition and supply chains, factory siting and manufacturing processes, and any other business development related issues can be done at this stage.

The second stage of lean commercialization is "Developing the prototype". This stage is also common to many commercialization frameworks, though under different names. For example, Maine and Garnsey (2007) called it "customization of R\&D", Pietzsch and colleagues (2009) name it "design and development", and Gbadegeshin (2017b) termed it "prototyping and development". Meanwhile, the lean startup methodology called it "minimum viable product", which simply means a working prototype that can be put in front of customers (Furr et al., 2014; Gbadegeshin \& Heinonen, 2016; Ries, 2011). Thus, this stage of lean commercialization is expected to result in the development of a workable prototype with basic functions and safety features. The main aim of a minimum viable product is to examine the workability of a new idea with potential customers (Blank, 2013; Furr et al., 2014; Ries, 2011). Likewise, lean commercialization aims to have a working prototype with the main functions and safety so that it can be tested by consumers. Functional features ensure that the technology achieves its purpose, while safety features protect the users. In lean commercialization, this form of prototype enables a firm to validate the conceptualization of the new technology, as others have noted (Apilo et al., 2015; Gbadegeshin, 2017b; Hemilä \& Jaring, 2018; Shimasaki, 2018).

The third stage is "Minimum viable product testing", or "MVP testing". Testing is an important phase of any commercialization process. Some commercialization scholars, (e.g., Maine \& Garnsey, 2007; Pietzsch et al., 2009) found that testing enabled commercialization teams to validate their new technologies. Similarly, scholars examining the lean startup methodology argue that testing reveals the "practicality" or "reality" of the new technology (e.g., Apilo et al., 2015; Gbadegeshin \& Heinonen, 2016; Ibba et al., 2018; Järvinen et al., 2014; Kruuti, 2016; Moogk, 2012; Shimasaki, 2018; Tran, 2015). Thus, this stage in lean commercialization pro- cess examines the functionality of the technology while also validating its business potential. Testing is expected to include (but is not limited to) market, technical, and business model tests. In all cases, the testing must be documented to inform the next stage.

The fourth stage is "Analyzing test data". This stage is not commonly pronounced in many commercialization frameworks. However, this stage is an integral part of the lean startup methodology. Therefore, with lean commercialization, users employ analysis tools to synthesize any collected data. In contrast to the lean startup methodology, which emphasizes analytics (i.e., quantitative analysis) (Blank, 2013; Maurya, 2012; Ries, 2011), any form of data analysis can be used with lean commercialization, whether based on qualitative or quantitative data. For example, some empirical studies (e.g., Gbadegeshin \& Heinonen, 2016; Ibba et al., 2018; Järvinen et al., 2014) have shown that different types of information are often collected during minimum viable product tests. Thus, it is recommended that, for lean commercialization, users of the methodology should be open-minded in collecting and analyzing their data. Such an attitude would enable the users to deduce insights from their tests, as explained by Erickson (2015), Furr and colleagues (2014), and Hemilä and Jaring (2018). Additionally, the tests can be done in different market segments and geographical locations so that mutual understanding of market and customers can be attained.

Test results can be positive, neutral, and negative. A test result is positive if the collected data showed that the new technology fulfils its primary purpose, potential customers are satisfied with it, or a business model is able to be achieved. This kind of result is often difficult with the first minimum viable product test, but it is possible. In contrast, a test result is negative when the aforementioned conditions are not met. For example, if the technology had a functional problem, if potential consumers did not have a good experience, or if a good business model could not be developed. A test result is neutral when the results are mixed or insufficient to draw conclusions.

The last stage of lean commercialization stage is "Making decisions". Ries (2011) advocates failing quickly, learning lessons, and thinking about the way forward. Lean commercialization shares this view, at least partially, by encouraging commercialization teams to make a decision about whether to continue or restart their new high-tech commercialization process in this 


\section{Lean Commercialization: A New Framework for Commercializing High Technologies Saheed A. Gbadegeshin}

final stage. A positive result should encourage teams to continue with full commercialization, but a neutral result suggests that the opportunity should be pivoted. Pivoting means that problems discovered in the minimum viable product test are addressed and re-tested, the minimum viable product is introduced to a new market, or the new technology is repurposed. However, pivoting does not mean that the new technology needs to start again from stage one. According to Gbadegeshin and Heinonen (2016), pivoting can start from the prototype development stage. Similarly, the empirical cases in this study confirmed that pivoting could start from this stage. Additionally, developing a new prototype might not be necessary in some cases; thus, lean commercialization users are advised to examine the test result critically before pivoting, because high technology is expensive, tedious, and resource-intensive to develop (Gbadegeshin, 2018a). Lastly, commercialization activities should be restarted if the minimum viable product test is negative. This means that lean commercialization users need to start the whole process afresh.

In summing up, lean commercialization is designed to reduce waste, minimize resource use, improve the utilization of a business opportunity, and create a sustainable business or help grow an existing business. Users of the framework must consider the nature of the new high technology and its related services and solutions, the formation of a commercialization team, and the nature of the target market. The nature of new technology determines the stages and sub-activities of lean commercialization. Similarly, the composition of the commercialization team helps or hinders the commercialization process (Gbadegeshin, 2017b). Most importantly, targeting a market determines what different factors and actors need to be considered in the commercialization process (Al Natsheh et al., 2015); hence, this consideration is essential in the application of the lean commercialization framework.

\section{Conclusion}

Commercializing scientific expertise that has been developed over a period of time is for developing and sustaining new and old businesses (Still, 2017). Similarly, transforming new technologies that have been developed from series of research and development investments is an important source of income for companies and government (Cornford, 2002; Gibson \& Naquin, 2011; Hindle \& Yencken, 2004). Hence, converting inventions or innovations into consumable products and services is part of the third mission of universities, after teaching and research (Clark, 1998; Etzkowitz et al., 2008; Foss \& Gibson, 2015; Guerrero et al., 2016). Making new technologies available and acceptable in marketplaces (Tanev \& Frederiksen, 2014) requires the creation of new businesses, the revamping of existing enterprises, and the employment of people (Gbadegeshin, 2017a, b; Still, 2017). Therefore, the commercialization of high-technologies is crucial for economic development (Banerjee \& Cole, 2011; Baptista \& Preto, 2011).

Naturally, high-technologies are expensive to commercialize. For example, Al Natsheh and co-authors (2015) pinpoint that, for commercializing Quantum Key Distribution technology (a high-technology for cybersecurity), various issues need to be addressed, including technical development, technology validation/certification, technology infrastructure, scattered and small markets, supply chain, after-sales services, and customer orientation/awareness. These issues make the commercialization of that high-technology challenging. Moreover, high-technologies are made more complicated by the advent of digitalization (Gbadegeshin, 2018b). In fact, more new high-technologies are expected to emerge as digitalization continues to evolve (Gbadegeshin, 2018b; Parviainen et al., 2017). With all these factors, employing a new logic or improving an old logic is necessary. This is the main motivation for proposing lean commercialization, which is developed from studying different high-technologies from different industries.

Lean commercialization, as its name implies, is a combination of lean/agile and commercialization knowledge. Its primary aim is to assist technology entrepreneurs and technology-based companies to commercialize their new high-technologies, without investing a huge amount of money and other resources. It helps users to validate their high-technologies and business models quickly. It also helps users to learn from their trials and simultaneously develop market and customers for their technologies. It aims to motivate potential entrepreneurs, scientists, and engineers to move forward with their innovations and acquire knowledge even if resources are scarce.

Although lean commercialization has its roots in the lean startup methodology, it has connections with other theories/frameworks such as bricolage and effectuation (Apilo et al., 2015). Briefly, bricolage originates from work of Lévi-Strauss (1966) and involves simply 


\section{Lean Commercialization: A New Framework for Commercializing High Technologies Saheed A. Gbadegeshin}

"making do" with current resources. It also refers to the creation of something new from little available resources or by combining various limited resources (Baker \& Nelson, 2005; Fisher, 2012; Gbadegeshin, 2018b). Similarly, effectuation, as propounded by Sarasvathy (2001), is a process of identifying and exploiting a business opportunity with limited available resources, and by employing affordable loss logic. This theory deals with business opportunities with a high level of uncertainty (Fisher, 2012).

Therefore, lean commercialization contributes to the theory of commercialization and entrepreneurship. Its framework is simple and easy-to-understand. It can be used for training scientists and engineers. Thus, the lean commercialization framework is useful for teaching technology entrepreneurship. Similarly, the lean commercialization framework can be used by practitioners, especially commercialization teams and commercialization project staff. Thus, lean commercialization makes a contribution to the practice of commercialization.

Lean commercialization is promising but it does have some limitations. First, lean commercialization was developed from a case study research methodology. This method is usually constrained in terms of the ability to generalize the results (Creswell, 2009; Eriksson \& Kovalainen, 2008; Yin, 2003). This constraint limits the logic to high-technologies in similar case contexts as studied here. However, lean commercialization can be applied to any high-technologies, or even "medium" or "low" technologies, depending on the user, because this methodological limit does not affect the quality of the framework. Second, lean commercialization was developed in the context of Finland, which is one of the most technologically advanced countries in the world (Kärki et al., 2017; Statistics Finland, 2018; World Economic Forum, 2018). This means that certain factors might have facilitated or hindered commercialization activities in the case studies, and these factors might be not present in the countries of other potential users of the lean commercialization framework. Thus, countryspecific factors, such as R\&D funding system, entrepreneurship policy, and ICT infrastructure, might create a limitation in applying the framework, but these factors do not undermine lean commercialization logic. Nonetheless, these limitations call for testing of lean commercialization in other contexts so that the framework can be validated.

\section{Acknowledgements}

The author would like to thank the Finnish Cultural Foundation, the Foundation for Economic Education in Finland (Liikesivistysrahasto), the Turku University Foundation, Turun Kauppaseura Foundation, Turku TOP-Säätiö, and the Turku School of Economics Support Foundation (Matti Koivurinnan säätiö) for their financial support. The author would also like to thank his supervisors: Professor Jarna Heinonen and Professor Anne Kovalainen. He also thanks his colleague, Mr. Ezak Ofem, for his feedback on the manuscript.

\section{About the Author}

Saheed A. Gbadegeshin is a PhD Candidate at Turku School of Economics, University of Turku, Finland. His research interests include commercialization, high technology, the lean startup methodology, entrepreneurship, business internationalization, and family-run businesses. He holds an MSc degree in Entrepreneurship from the University of Jyväskylä and an MBA in International Business Management from Turku University of Applied Sciences in Finland.

\section{References}

Abd Rahim, N., Mohamed, Z. B., \& Amrin, A. 2015. Commercialization of Emerging Technology: The Role of Academic Entrepreneur. Procedia - Social and Behavioral Sciences, 169: 53-60. https://doi.org/10.1016/j.sbspro.2015.01.285

Al Natsheh, A., Gbadegeshin, S. A., Rimpiläinen, A., \& Mainela, T. 2013. Technology Based Entrepreneurship: Measurement Technology Perspective. Interdisciplinary Journal of Research in Business, 2(9): 26-42.

Al Natsheh, A., Gbadegeshin, S. A., Rimpiläinen, A., ImamovicTokalic, I., \& Zambrano, A. 2014. Building a Sustainable Start-Up? Factors to Be Considered During the Technology Commercialization Process. Journal of Advanced Research in Entrepreneurship and New Venture Creation, 1(1): 4-19.

Al Natsheh, A., Gbadegeshin, S. A., Rimpiläinen, A., Imamovic-Tokalic I., \& Zambrano, A. 2015. Identifying the Challenges in Commercializing High Technology: A Case Study of Quantum Key Distribution Technology. Technology Innovation Management Review, 5(1): 26-36.

http://doi.org/10.22215/timreview/864

Amadi-Echendu, J. E., \& Rasetlola, R. T. 2011. Technology Commercialization Factors, Frameworks and Models. In Proceedings of the 2011 IEEE International Technology Management Conference (ITMC): 144-148. https://doi.org/10.1109/ITMC.2011.5995939 


\section{Lean Commercialization: A New Framework for Commercializing High Technologies Saheed A. Gbadegeshin}

Amadi-Echendu, J. E., \& John, A. 2008. On the Commercialization of Trailing Knowledge and IP. In Proceedings of the PICMET'08 Conference, Cape Town. Paper ID: 08R0018. https://doi.org/10.1109/PICMET.2008.4599765

Apilo, T., Fiegenbaum, I., Still, K., Jaring, P., Wallin, A., Komi, M., \& Suciu, G. 2015. Current State of Art and Practice, Industrial Needs for Methodologies. Accelerate Project Deliverable D1.1. Version: $1.0,2015$

Baker, T., \& Nelson, R. E. 2005. Creating Something from Nothing: Resource Construction through Entrepreneurial Bricolage. Administrative Science Quarterly, 50(3): 329-366. https://doi.org/10.2189/asqu.2005.50.3.329

Banerjee, P. M., \& Cole, B. M. 2011. Globally Radical Technologies and Locally Radical Technologies: The Role of Audiences in the Construction of Innovative Impact in Biotechnology. IEEE Transactions on Engineering Management, 58(2): 262-274. https://doi.org/10.1109/TEM.2010.2049851

Baptista, R., \& Preto, M. T. 2011. New Firm Formation and Employment Growth: Regional and Business Dynamics. Small Business Economics, 36(4): 419-444. https://doi.org/10.1007/s11187-009-9254-y

Blank, S. 2013. Why the Lean Start-Up Changes Everything. Harvard Business Review, 91(5): 64-70,

Blank, S., Benjamin, S., Turner, E., Eisenberg, I., Warren, H., TelleenLawton, D., \& Hassin, B. 2013. "Lean" Is Shaking Up the Entrepreneurial Landscape: Interaction. Harvard Business Review, 91(7/8): 14-15.

Bradley, S. R., Hayter, C. S.. \& Link, A. N. 2013. Models and Methods of University Technology Transfer. Foundations and Trends in Entrepreneurship, 9(6): 571-650.

http://dx.doi.org/10.1561/0300000048

Clark, B. R. 1998. Creating Entrepreneurial Universities: Organisational Pathways of Transformation. Oxford, UK: Elsevier.

Cornford, A. B. 2002. Innovation and Commercialization in Atlantic Canada: Research Project - Final Report. Moncton, NB: Atlantic Canada Opportunities Agency (ACOA).

http://publications.gc.ca/pub?id=365765\&sl=0

Creswell, J. W. 2009. Research Design: Qualitative, Quantitative, and Mixed Methods Approaches (3rd Ed.). London: Sage Publication Inc.

Denzin, N., \& Lincoln Y. (Eds.) 2000. Handbook of Qualitative Research. London: Sage Publication Inc.

Donelan, J. 2013. Do Lean Start-up Principles Have a Place in the Enterprise? The Next Web, August 6, 2013. Accessed September 15, 2018:

http://thenextweb.com/entrepreneur/2013/08/06/do-leanstartup-principles-have-a-place-in-the-enterprise/

Eldred, E. W., \& McGrath, M. E. 1997. Commercializing New Technology. Research-Technology Management, 40 (1): 41-47. https://doi.org/10.1080/08956308.1997.11671102

Erickson, L. B. 2015. Book Review: The Innovator's Method: Bringing the Lean Startup into Your Organization. Research-Technology Management, 58(1): 62-63.

Eriksson, P., \& Kovalainen, A. 2008. Qualitative Methods in Business Research. London: Sage Publications Ltd.
Etzkowitz, H., Ranga, M., Benner, M., Guaranys, L., Maculan, A. M., \& Kneller, R. 2008. Pathways to the Entrepreneurial University: Towards a Global Convergence. Science and Public Policy, 35(9): 681-695.

https://doi.org/10.3152/030234208X389701

Eurostat. 2016. High-Technology Versus Low-Technology Manufacturing. Eurostat Statistics Explained. Last Accessed September 15, 2018:

https://ec.europa.eu/eurostat/statistics-

explained/index.php?title=Archive:High-technology_versus_lowtechnology_manufacturing

Fisher, G. 2012. Effectuation, Causation, and Bricolage: A Behavioral Comparison of Emerging Theories in Entrepreneurship Research. Entrepreneurship Theory and Practice, 36(5): 1019-1051. https://doi.org/10.1111/j.1540-6520.2012.00537.x

Foss, L., \& Gibson, D. V. 2015. The Entrepreneurial University: Context and Institutional Change. Abingdon, UK: Routledge.

Furr, N., Dyer, J., \& Christensen, C. M. 2014. The Innovator's Method: Bringing the Lean Startup Into Your Organization. Boston, MA: Harvard Business Press.

Gaffney, S., Lin, S., Miller, K., Nilsson, H., Ravala, S., \& Unnikrishnan, M. 2014. Lean Start-up Methodology for Enterprises: How Established Companies Can Leverage Lean Startup Methodology for Sustaining and Disruptive Innovation. Insights in Engineering Leadership White Paper. Berkeley, CA: University of California Berkeley.

https://ikhlaqsidhu.files.wordpress.com/2014/08/elpp-project-1lean-startup-for-enterprises-final-3.pdf

Gbadegeshin, S. A., \& Heinonen, L. 2016. Application of the Lean Start-Up Technique in Commercialisation of Business Ideas and Innovations. International Journal of Business Management and Research, 43(1): 1270-1285.

Gbadegeshin, S. A. 2017a. Stating Best Commercialization Method: An Unanswered Question from Scholars and Practitioners. International Journal of Social, Behavioral, Educational, Economic, Business and Industrial Engineering, 11(5): 1088-1094.

Gbadegeshin, S. A. 2017b. Commercialization Process of High Technologies: Case Study of Finnish University Spin-off. Academy of Entrepreneurship Journal, 23(2): 1-22.

Gbadegeshin, S. A. 2018a. Commercialization Skills: Necessity for High Technology Entrepreneurs in Digital Era. In Proceedings of Future Technologies Conference 2018: Advances in Intelligent Systems and Computing, Forthcoming.

Gbadegeshin, S. A. 2018b. Bricolage: Theoretical and Contemporary Uses in Entrepreneurship Studies. Journal of Asia Entrepreneurship \& Sustainability, Forthcoming.

Gibson, D. V., \& Naquin, H. 2011. Investing in Innovation to Enable Global Competitiveness: The Case of Portugal. Technological Forecasting \& Social Change, 78(8): 1299-1309.

https://doi.org/10.1016/j.techfore.2011.04.004

Grohn, K., Moody, K., Wortel, D., LeClair, N., Traina, A., Zluhan, E., \& Feuer, G. 2015. Lean Start-Up: A Case Study in the Establishment of Affordable Laboratory Infrastructure and Emerging Biotechnology Business Models. Journal of Commercial Biotechnology, 21(2): 60-68. 


\section{Lean Commercialization: A New Framework for Commercializing High Technologies Saheed A. Gbadegeshin}

Guerrero, M., Urbano, D., Fayolle, A., Klofsten, M., \& Mian, S. 2016. Entrepreneurial Universities: Emerging Models in the New Social and Economic Landscape. Small Business Economics, 47(3): $551-563$.

https://doi.org/10.1007/s11187-016-9755-4

Hakin, E. 2014. How Lean Startup Is Being Applied in Established Organisations. Middlesex, UK: Foote Evans Breslin, Digital Product Consultancy.

Harms, R., Marinakis, Y., \& Walsh, S. T. 2015. Lean Startup for Materials Ventures and Other Science-Based Ventures: Under What Conditions Is It Useful? Translational Materials Research, 2(3).

https://doi.org/10.1088/2053-1613/2/3/035001

Hart, M. A. 2012. Book Review: The Lean Startup: How Today's Entrepreneurs Use Continuous Innovation to Create Radically Successful Businesses. Journal of Product Innovation Management, 29(3): 508-509.

https://doi.org/10.1111/j.1540-5885.2012.00920_2.x

Hemilä, J., \& Jaring, P. 2018. Accelerating Idea to Market Process in Manufacturing Industries. ACTA Technica Corviniensis - Bulletin of Engineering, 11(1): 27-30.

Hemilä, J., \& Vanhanen, J. 2016. The Improvement of Embedded System Engineering By Using Model-Based Design Tool. In Proceedings of 8th International Scientific Conference Management of Technology - Step to Sustainable Production: 37-42, Porec, Istria, Croatia.

Hindle, K., \& Yencken, J. 2004. Public Research Commercialisation, Entrepreneurship and New Technology Based Firms: An Integrated Model. Technovation, 24(10): 793-803. https://doi.org/10.1016/S0166-4972(03)00023-3

Ibba, S., Pinna, A., Baralla G., \& Marchesi, M. 2018. ICOs Overview: Should Investors Choose an ICO Developed with the Lean Startup Methodology? In J. Garbajosa, X. Wang, \& A. Aguiar (Eds), Agile Processes in Software Engineering and Extreme Programming. XP 2018: Lecture Notes in Business Information Processing, Volume 314. Cham, Switzerland: Springer.

https://doi.org/10.1007/978-3-319-91602-6_21

Järvinen, J., Huomo, T., Mikkonen, T., \& Tyrväinen, P. 2014. From Agile Software Development to Mercury Business. In L. Casper \& K. Smolander (Eds.), Software Business: Towards Continuous Value Delivery: 5th International Conference, ICSOB 2014: 58-71. Paphos, Cyprus, June 16-18, 2014.

Kärki, K., Lähde, A., Mattila, P., \& Piper, E. E. 2017. Finland Celebrates 100 Years of Independence - Here Are 100 Reasons Why It Is the Greatest Country on Earth. Aamulehti, December 6, 2017. Accessed September 15, 2018:

https://www.aamulehti.fi/uutiset/finland-celebrates-100-years-ofindependence-here-are-100-reasons-why-it-is-the-greatestcountry-on-earth-200584816/

Kilpatrick, J. 2003. Lean Principles. Orem, UT: Utah Manufacturing Extension Partnership.

http://yourcareeracademy.com/yca/assets/uploads/lib_file/Lean \%20Principles\%20-\%20overview.pdf

Kruuti, T. 2016. Customer Understanding and the Lean Startup Approach in New Business Commercialization: Case Study of a De Alio Multinational Commercializing a New Product to an Unfamiliar Market. Master's Thesis, Aalto University, Finland. https://aaltodoc.aalto.fi/handle/123456789/24488
Lalic, M., Calopa, M. K., \& Horvat, J. 2012. Lean Startup in Croatia Does the Croatian Startup Scene Develop Effective Enterprises? TEM Journal, 1(3): 200-207,

Maine, E., \& Garnsey, E. 2007. The Commercialisation Environment of Advanced Materials Ventures. International Journal of Technology Management, 39(1/2): 49-71. https://doi.org/10.1504/IJTM.2007.013440

Maurya, A. 2012. Running Lean: Iterate from Plan A to a Plan that Works. Sebastopol, CA: O'Reilly Media, Inc.

Meyers, A. D. 2009. Book Review: Commercialisation of Innovative Technologies: Bringing Good Ideas to the Marketplace. Journal of Commercial Biotechnology, 15(4): 374-375. https://doi.org/10.1057/jcb.2009.18

Miles, M. B., \& Huberman, A. M. 1994. From Qualitative Data Analysis: An Expanded Sourcebook (2nd Ed.) Thousand Oaks, CA: Sage Publications.

Miski, A. 2014. Development of a Mobile Application Using the Lean Startup Methodology. International Journal of Scientific \& Engineering Research, 5(1): 1743-1748.

Moogk, D. R. 2012. Minimum Viable Product and the Importance of Experimentation in Technology Startups. Technology Innovation Management Review, 2(3): 23-26. http://doi.org/10.22215/timreview/535

Morse, J. M., Barnett, N., Mayan, M., Olson, K., \& Spiers, J. 2002. Verification Strategies for Establishing Reliability and Validity in Qualitative Research. International Journal of Qualitative Methods, 1(2): 13-22.

https://doi.org/10.1177/160940690200100202

Munch, J., Fagerholm, F., Johnson, P., Pirttilahti, J. Torkkel, J., \& Järvinen. J. 2013. Creating Minimum Viable Products in IndustryAcademia Collaborations. In Proceedings of the Lean Enterprise Software and Systems Conference (LESS 2013). Galway, Ireland, December 1-4, 2013.

https://tuhat.halvi.helsinki.fi/portal/files/29946700/0bcc9075da89 4620f1be7f59ced5164541f1bb5f.pdf

Parviainen, P., Tihinen, M., Kääriäinen, J., \& Teppola, S. 2017. Tackling the Digitalization Challenge: How to Benefit from Digitalization in Practice. International Journal of Information Systems and Project Management, 5(1): 63-77. https://doi.org/10.12821/ijispm050104

Perkmann, M., Tartari, V., McKelvey, M., Autio, E., Broström, A., D’Este, P., Fini, R., Geuna, A., Grimaldi, R., Hughes, A., Krabel, S., Kitson, M., Llerena, P., Lissoni, F., Salter, A., \& Sobrero, M. 2013. Academic Engagement and Commercialisation: A Review of the Literature on University-Industry Relations. Research Policy, 42(2): 423-442.

https://doi.org/10.1016/j.respol.2012.09.007

Pietzsch, J. B., Shluzas, L. A., Paté-Cornell, M. E., Yock, P. G., \& Linehan, J. H. 2009. Stage-Gate Process for the Development of Medical Devices. Journal of Medical Devices, 3 (021004): 1-15. https://doi.org/10.1115/1.3148836

Rosa, J. \& Rose, A. 2007. Report on Interviews on the Commercialization of Innovation. Ottawa, CA: Statistics Canada.

Ries, E. 2011. The Lean Start-Up: How Constant Innovation Creates Radically Successful Businesses. London: Penguin. 


\section{Lean Commercialization: A New Framework for Commercializing High Technologies Saheed A. Gbadegeshin}

Schrier, D. \& Hallin, L. 2017. Profile of the British Columbia Technology Sector. Innovation and Citizens' Services. Victoria, BC: British Columbia Statistics. Accessed September 15, 2018: http://www.bcstats.gov.bc.ca/StatisticsBySubject/BusinessIndustr y/HighTechnology.aspx

Shimasaki, C. 2018. Moleculera Labs Story: Lessons in a Capital Efficient Start-Up. Journal of Commercial Biotechnology, 24(1): 97-104.

https://doi.org/10.5912/jcb858

Silva, S. E. P., Calado, R. D., Silva, M. B., \& Nascimento, M. A. 2013. Lean Startup Applied in Healthcare: A Viable Methodology for Continuous Improvement in the Development of New Products and Services. IFAC Proceedings Volumes, 46(24): 295-299. https://doi.org/10.3182/20130911-3-BR-3021.00054

Speser, P. 2008. What Every Researcher Needs to Know About Commercialisation. Providence, RI: Foresight Science and Technology Inc.

Statistics Finland. 2018. Finland Among the Best in the World. Helsinki: Statistics Finland. Accessed September 15, 2018: https://www.stat.fi/ajk/satavuotiassuomi/suomimaailmankarjessa _en.html

Steenhuis, H., \& de Bruijn, E. J. 2006. High Technology Revisited: Definition and Position. In Proceedings of the 2006 IEEE International Conference on Management of Innovation and Technology: 1080-1084. Singapore, June 21-23, 2006. https://doi.org/10.1109/ICMIT.2006.262389

Still, K. 2017. Accelerating Research Innovation by Adopting the Lean Startup Paradigm. Technology Innovation Management Review 7(5): 32-43.

http://doi.org/10.22215/timreview/1075

Tanev, S., \& Frederiksen, M. H. 2014. Generative Innovation Practices, Customer Creativity, and the Adoption of New Technology Products. Technology Innovation Management Review, 4(2): 5-10. http://doi.org/10.22215/timreview/763
Tran, B. 2015. Applying Lean Methodologies to the Development of an Entrepreneurial Venture in Education. Doctoral dissertation, Harvard Graduate School of Education, Boston, MA. http://nrs.harvard.edu/urn-3:HUL.InstRepos:16645018

Wong, F. 1990. High-Technology at Work. Perspectives on Labour and Income, 2(1), Article No. 2.

World Economic Forum. 2018. The Global Competitiveness Report 2017-2018: Innovation. Cologny, Switzerland: World Economic Forum.

http://reports.weforum.org/global-competitiveness-index-20172018/competitiveness-rankings $/$ \#series=GCI.C. 12

Wright, M., Siegel, D. S., \& Mustar, P. 2017. An Emerging Ecosystem for Student Start-Ups. The Journal of Technology Transfer, 42(4): 909-922. https://doi.org/10.1007/s10961-017-9558-z

Yin, R. K. 2003. Case Study Research: Design and Methods, (2nd Ed): Thousand Oaks, CA: Sage Publications Inc.

Youtie, J., \& Shapira, P. 2017. Exploring Public Values Implications of the I-Corps Program. Journal of Technology Transfer, 42(6): 1362-1376. https://doi.org/10.1007/s10961-016

Citation: Gbadegeshin, S. A. 2018. Lean Commercialization: A New Framework for Commercializing High Technologies. Technology Innovation Management Review, 8(9): 50-63. http://doi.org/10.22215/timreview/1186

Keywords: lean commercialization, high technologies, lean startup, technology-based companies, Finland 


\section{Academic Affiliations and Funding Acknowledgements}

Canadà
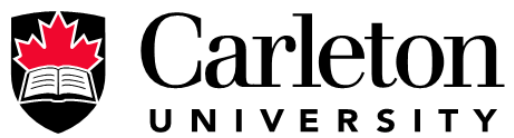

U N I V E R S I T Y

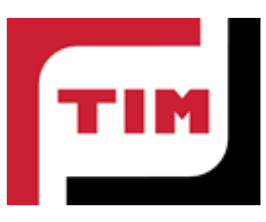

The Federal Economic Development Agency for Southern Ontario (FedDev Ontario; feddevontario.gc.ca) is part of the Innovation, Science and Economic Development portfolio and one of six regional development agencies, each of which helps to address key economic challenges by providing regionallytailored programs, services, knowledge and expertise.

- The TIM Review receives partial funding from FedDev Ontario's Investing in Regional Diversification initiative.

Technology Innovation Management (TIM; timprogram.ca) is an international master's level program at Carleton University in Ottawa, Canada. It leads to a Master of Applied Science (M.A.Sc.) degree, a Master of Engineering (M.Eng.) degree, or a Master of Entrepreneurship (M.Ent.) degree. The objective of this program is to train aspiring entrepreneurs on creating wealth at the early stages of company or opportunity lifecycles.

- The TIM Review is published in association with and receives partial funding from the TIM program. 